\title{
LIMITATION OF CLAIMS IN POLISH AND UKRAINIAN \\ CIVIL CODE AGAINST THE BACKGROUND OF THE PRINCIPLES OF EUROPEAN CONTRACT LAW AND THE GERMAN CIVIL CODE
}

\author{
Sibilla Buletsa* \\ Department of Civil Law and Process, Law Faculty, Uzhhorod National University, Ukraine \\ E-mail: sibilla.buletsa@uzhnu.edu.ua; sbuleca@gmail.com
}

\section{Piotr Zakrzewski}

Department of Civil Law, John Paul II Catholic University of Lublin, Poland

E-mail: zakrzew@kul.lublin.pl

(Received: August 2019; Accepted: October 2019; Published: November 2019)

\begin{abstract}
The article deals with limitation of claims in Poland, Ukraine and Germany. The authors made a conclusion that the most liberal solution in the area of contractual regulation of limitation is provided in the German Civil Code, which allows shortening and prolonging the statutory limitation period, whereas the most severe is provided for in the Polish Civil Code, prohibiting it altogether. An indirect solution has been adopted by the Ukrainian Civil Code, which allows only the extension of the statutory limitation period. These different legislative solutions demonstrate that the national legislators are partially different in their view of the reasons justifying the statute of limitations. Newer prescription regulations, to which the German and Ukrainian ones belong, are largely similar to each other. The same can be said about the Polish academic project of the general section of the civil code. The Principles of European Contract Law have had a significant impact on teaching of civil law, as well as on national legislators.
\end{abstract}

Keywords: limitation, claims, property, principles, contract law, civil code

\section{Introduction}

In recent years many legal orders have been made to work out a new and better model for limiting claims. They resulted in either amendments to existing regulations, such as the German civil code [1], or parts of a new civil code, and the

\footnotetext{
* Corresponding author: Sibilla Buletsa.E-mail: sibilla.buletsa@uzhnu.edu.ua
} use, distribution, and reproduction in any medium, provided the original author and source are credited. 
Buletsa, S., Zakrzewski, P., (2019)

Limitation of claims in Polish and Ukrainian Civil Code against the background of the principles of european contract law and the German Civil Code

civil code of Ukraine [2]. In numerous cases the limitation model formulated in the

Principles of European Contract Law (PECL), characterized by uniformity, simplicity and transparency, and achieved by shortening and unifying the limitation periods and by referring to the criterion of knowledge of the entitled claim, served as inspiration for various legislative changes [3].

The objective of this article is to evaluate the selected limitation provisions, having appeared in Polish, Ukrainian and German Civil Codes in terms of their uniformity, simplicity and transparency in the light of the solutions found in the European Contract Law. The subject-matter of the analysis lies in the following: the subject of the limitation period, the length and the events commencing the limitation period, the effects, following the expiration of the limitation period, as well as the contractual regulation of the limitation periods in the indicated legal orders, along with assessment of their actual performance.

\section{The subject of limitation and the length of limitation period}

In accordance with the Civil code of Poland of April 23 $3^{\text {rd }}, 1964$ [4] only material property claims are subject to limitation (art. $117 \S 1$ of Polish civil code), while procedural and material non-property claims, such as non-property claims for the infringement of personality rights (art. 23, 24 of Polish civil code) do not lapse. This solution is justified in Polish literature, stipulated by the need to better protect the interests of non-material persons [5].

The Polish project of the civil code general section, prepared by Civil Law Codification Commission of term IV, valid over the period between 2011-2015 at Minister of Justice introduced some deviations from the existing solutions. According to it, the property claim is time-barred unless the special provision provides otherwise and non-property claims shall be time-barred if a specific provision provides so (art. 146 of the project of the general section of the civil code [6]).

Polish civil code includes general regulations, concerning financial claims and specific regulations with regard to certain types of claims (Polish civil code lays down diversified principles of limitation, depending on the type of a claim). We can distinguish the following types of claims: those, connected with administering business activity, periodic claims (art. 118 of Polish civil code), those, pronounced by the final judgment of the court (art. 125 of Polish civil code), as well as compensatory claims (art. $442^{1}$ of Polish civil code).

As far as the claims connected with managing business activity are concerned, it is worth mentioning that they still bear peculiarities of their own. Expiration period of such claims is significantly shorter. The reasons, determining the establishment of

64 S sciendo Journal of Legal Studies Volume 24 Issue 38/2019 ISSN 2457-9017; Online ISSN 2392-7054.

Web: publicatii.uvvg.ro/index.php/jls. Pages $63-94$ 
Buletsa, S., Zakrzewski, P., (2019)

Limitation of claims in Polish and Ukrainian Civil Code against the background of the principles of european contract law and the German Civil Code

special legal rules, concerning claims connected with managing business activity in Polish law were intended at accelerating economic turnover.

However, this solution possesses some shortfalls. It is rather doubtful whether an entrepreneur's claim, regarding managing business activity is the only one, based on the agreement, for instance, agency contract, or whether it is the one, resulting from an act of law, e.g., the claim of an entrepreneur on account of unjust enrichment or tort claims. Polish jurisdiction and literature are generally favour broad understanding of the business activity claims, including all the claims of an entrepreneur regardless of their basis, it being either a contract or an act of law [7]. This is a questionable stance since there is no connection between the claim, concerning unjust enrichment and the one on an entrepreneur's business activity. Alternatively, in German law claims connected with running business activity are formulated in quite a narrow way - they are those which result from contracts being entered into by an entrepreneur.

The determining factors for special legal regulations in Polish law, concerning periodic provisions arose as a result of preventing accumulation of recurring debts, for instance, long-term delay in paying rent which can be an excessive burden for a debtor, hence such liability cannot be satisfied over a short period of time.

In practice, however, it is still debatable whether the claim can be regarded as periodic, as, for instance, a claim for the dividend payment of the company, or whether it is of different nature. The Polish Supreme Court recently ruled that such a claim cannot be considered periodic [8], yet such a statement proves dubious.

In Polish law limitation periods, as a rule, tend to be longer and more diversified. According to the rule, claims lapse following a six years' failure to pay (art. 118, $125 \S 1$ sentence one, art. $120 \S 1$ sentence 1 of Polish civil code). However, it does not hold true for certain types of the abovementioned claims, since both the claims, connected with managing business activity, and periodic ones shall lapse after a three years' period, as well as periodic claims, stated by the final judgment of the court, which shall also lapse following a three years' term (art. $125 \S 1$ second sentence of Polish civil code.). According to art. $442^{1}$ of Polish civil code "the claim for the redress of the damage caused by a tort shall be barred by limitation after the lapse of three years from the day on which the person who suffered the damage learned about it and about the person liable to redress it. However, this period shall not be longer than ten years from the day on which the event that caused the damage occurred".

Prior to bringing to force a new law, the new Act of 13th April 2018 on Changing the Previous Act - Civil Code as well as some other acts, revised regulations, concerning limitation of claims, in terms of which the basic term of limitation was 10 years (art. 118 of Polish civil code), and the assessment of this solution was 
Buletsa, S., Zakrzewski, P., (2019)

Limitation of claims in Polish and Ukrainian Civil Code against the background of the principles of european contract law and the German Civil Code

negative. It is worth drawing attention to limitation period of tax claims, included in the act of $29^{\text {th }}$ August 1997, of tax code [9], which is substantially shorter, approximately three or five years (art. $68 \S 1-2$ of tax code). This comparison with public law illustrates that civil limitation periods are excessively long and fail to meet contemporary needs.

Therefore, it should not come as a surprise that the project of the general section of the civil code states that a basic limitation period is supposed to not exceed three years (art. 150 of Polish project of the general section of the civil code). The project also defines the so-called final limitation period. According to art. $151 \S 1$ of Polish project of the civil code general section of a claim expires at the latest ten years following the date of maturity.

On 9th July, 2018 the abovementioned Act of 13th April, 2018 on Changing the Previous Act - Civil Code, as well as some other acts, was brought into force, stipulating, i.e. curtailing the basic term of claims limitation from 10 to 6 years, which should be assessed positively ( art. 118 of Polish civil code).

Another solution has been adopted in Principles of European Contract Law, and partially in German civil code. The solutions adopted in Principles of European Contract Law are based on an assumption of an equal interpretation of all claims, regardless of whether it is a financial or non-financial claim, what kind of claim is being dealt with, or whether the claim results from a contract, an act of law, particularly, a tort or unjust enrichment. As a consequence, the same principles of limitation are applied to nearly all types of claims. It concerns, in particular, a length of the limitation period, as well as circumstances, leading to the distortion of the limitation period (art. 14:101 PECL) [10].

A demand for developing a unanimous and transparent limitation model of claims in PECL has also been determined by shortening and harmonization of limitation periods for almost all the claims. Shortening of limitation periods should also be understood as attributing greater importance to an encouraging function (pressure on an entitled to make them realize their rights quicker) [11].

In PECL, the so called regular limitation period is utterly short, being merely three years long, and including all the types of the claims. The only exception is the claims, granted by a judgment or a judicial decision of the arbitration court, as well as those, resulting from a document with enforceability clause as a writ of execution. Such claims shall lapse after ten years' period. It is absolutely justified, since in such a case there is no difficulty of proof whether the claim exists, as they are supported by official evidence [12].

In German civil code both financial and non-financial claims are subjected to limitation ( $\$ 194$ passage 1 of German civil code) but some claims in the area of family law do not lapse ( $\$ 194$ passage 2 of German civil code).

66 sciendo Journal of Legal Studies Volume 24 Issue 38/2019 ISSN 2457-9017; Online ISSN 2392-7054.

Web: publicatii.uvvg.ro/index.php/jls. Pages $63-94$ 
Buletsa, S., Zakrzewski, P., (2019)

Limitation of claims in Polish and Ukrainian Civil Code against the background of the principles of european contract law and the German Civil Code

It is also worth mentioning that certain claims are time-barred after specific terms 10 years. These are: claims for the transfer of ownership of a property, the establishment, transfer or removal of property rights or the change of its content, as well as the claim for consideration ( $\$ 196$ of German civil code). The basic threeyear limitation period is too short for such claims (for example tax clearance certificate [13].

The following claims are statute-barred after thirty years: damage claims based on intentional injury to life, limb, health, liberty or sexual self-determination, claims for return based on ownership, other real rights, sections 2018 [14], 2130 [15] and 2362 [16], as well as claims serving to assert the claims for return, claims that have been declared final and absolute, claims under enforceable settlements or enforceable documents, claims that have become enforceable upon being recognized in insolvency proceedings, and claims to reimbursement of the costs of execution ( $\$ 197$ passage 1 of German civil code). To the extent that claims under subsection(1), nos. 3 to 5 are concerned with periodically recurring acts of performance that will fall due in the future, the standard limitation period takes the period of thirty years ( $\$ 197$ passage 1 of German civil code) [17].

To compare, in Ukrainian civil code of January 16th 2003 [18] material property claims are subjected to limitation (art. 258 of Ukrainian civil code). Limitation period is the expiration of the term, and the term, in turn, is one of the essential elements of the limitation as an independent legal category [19]. The Ukrainian civil law provides that a person is entitled to protect his property rights, specifically allocating protection against the refutation of inaccurate information, contained in the media. The limitation periods are the material terms of the violated rights and legitimate interests, as well as the time limits of the existence of the subjective right in process [20]. The subject of the legal institute of limitation focuses on exclusively legal relations, associated with the possibility of protection of the violated law. This opportunity is implemented through a safeguard obligation, the subject-matter of which is the right of a creditor to enforce the claim, and a debtor's duty is to subject to this coercion. Such coercion is carried out by a court, i.e. a specially authorized judicial body of the state. The demand of the authorized person concerning the one under obligation, provided with the means of state coercion, is the subjetct-matter of the corresponding security obligation. It is precisely this claim that is of a procedural nature and subject to the limitation period [21].

According to Ukrainian Civil Code there are two types of limitation periods:

1) General (3 years of Article 257 of the Civil Code. In Ukraine there was an attempt to make amendmens to the Civil Code, hence there an extended limitation period of 5 years was introduced, applying to the requirements for the invalidation 
Buletsa, S., Zakrzewski, P., (2019)

Limitation of claims in Polish and Ukrainian Civil Code against the background of the principles of european contract law and the German Civil Code

of an act committed under the influence of violence or deception, whereas the one for 10 years applies to claims for the use of the consequences of a void transaction, however both of them were canceled in 2011 due to their inefficiency.

2) Special, that is, abbreviated, in particular, as specified in 258 of Ukrainian Civil Code, the following requirements shall be established for 1 year [22].

In the Civil Code of Ukraine, there is no other special type of limitation period than a 1- year limitation period. However, separate legislative acts provide for shorter periods of limitation, which are as follows: 1 month, 3 months, 6 months [23]. For instance, paragraph 3.4 of the resolution of the Supreme Commercial Court of Ukraine dated May 29, 2013, No. 10 "On some issues of the practice of applying the limitation period in the settlement of commercial disputes" explained that stipulated by Article 46 of the mortgage "Law" three months for appeal in court Public tenders by their very nature are a special (shortened) limitation period in relation to the corresponding claims of persons specified in this norm (mortgagee, mortgagor, debtor, other participant in public bidding) [24]. Although in the Article 258 of the Civil Code of Ukraine the list of special time limits for limitation is set out as exhaustive, they may also be established by special legislation. For example, part 3 and 4 of Article 10 of the Law "On Protection of Consumer Rights" specifies the special time limits for limitation of the demand for the free removal of shortcomings under the contract: reduced up to 2 years, in case of identifying common defects in the work performed, and long -one up to 10 years in case of significant deficiencies [25]; the Code of Merchant Shipping of Ukraine sets a twoyear special limitation period (art. 389) [26]. Special periods of limitation are also specified in other sectoral laws (Part 1 of Article 223 of the Labor Code of Ukraine [27], Part 2 of Article 72 of the Family Code of Ukraine [28], Article 212 of the Commercial Code of Ukraine [29], etc.), but the regulation, calculation and application of their Consequences are carried out in accordance with the Civil Code of Ukraine. Therefore, the establishment of special time limits for limitation of actions is not restricted only to the Civil Code of Ukraine, in particular Article 258, and may be applied in other cases provided by law.

We have observed that limitation period poses a barrier to the implementation of the right to a fair trial. Proceedings prescribe the right to appeal to a court, depending on the factor of time, that is, in other words, it determines this right by a certain circumstance, being the circumstance of time. Consequently, limitation period constitutes a restriction on the right to take an action to a court, or rather, a restriction on the right to access a court. Limitation period is a time limitation of the right to access to a court. The fact that the right to access to a court is limited in time is not in itself a violation of fundamental human rights. Time limits for the validity of the right to a judicial remedy are incompatible with the provisions of the

68 Sciendo Journal of Legal Studies Volume 24 Issue 38/2019 ISSN 2457-9017; Online ISSN 2392-7054.

Web: publicatii.uvvg.ro/index.php/jls. Pages $63-94$ 
Buletsa, S., Zakrzewski, P., (2019)

Limitation of claims in Polish and Ukrainian Civil Code against the background of the principles of european contract law and the German Civil Code

European Convention on Human Rights (ECHR), the only one where such borders are not reasonably justified in terms of the criteria developed in case-law of the ECHR [30]. The limitation period should not be obviously and excessively short. The ECHR has repeatedly emphasized that it cannot replace a national legislator and determine which length of time is most appropriate in a particular situation.

It is worth mentioning that "right to a court", of which the right of access presents merely one aspect, is not absolute. These legitimate restrictions include the imposition of statutory limitation periods, which, as the Court has held in personal injury cases, "serve several important purposes, namely to ensure legal certainty and finality, protect potential defendants from stale claims which might be difficult to counter and prevent the injustice which might arise if courts were required to decide upon events which took place in the distant past on the basis of evidence which might have become unreliable and incomplete because of the passage of time" [31].

On the other hand, in Ukraine there is Article 268 of Civil Code of Ukraine that clearly defines the requirements, which are not subject to limitation, namely: 1) on the demand arising from the violation of personal non-property rights, except for cases, established by law; 2) upon request of the depositor to the bank (financial institution) on the issue of the deposit; these relationships are time-consuming, however their expiry time is indefinite. The corresponding provision st.268 of the Civil Code of Ukraine can be explained, as well, by the legislator's desire to maximize the interests of the bank's clients in order to encourage them to invest their money in the economy of Ukraine; 3) at the request of compensation for damage caused by injury, other damage to health or death, except for cases of such damage caused by defects of goods that are movable property, including those that form part of other movable or immovable property, including electricity; 4) at the request of the insured (to the insurer for the implementation of insurance payments (insurance indemnity). In other words, if the damage might be confirmed by the insurer indefinitely from the moment of the occurrence of the insured event, the insured amount must be paid out indefinitely; 5) at the request of the central executive authority, which implements the state policy in the field of the state material reserve, in relation to the fulfillment of obligations arising from the Law of Ukraine "On the State Material Reserve" [32]; 6) on the demand for the invalidation of an agreement the subject of which is the alienation of a hostel as an object of immovable property and / or its part covered by the Law of Ukraine "On ensuring the realization of housing rights of dormitory residents", the invalidation of the certificate of title to such a hostel as an object of real estate and / or a part thereof, the invalidation of the act of transferring such a hostel as an object of immovable property and / or its part to the authorized capital of the partnership 
Buletsa, S., Zakrzewski, P., (2019)

Limitation of claims in Polish and Ukrainian Civil Code against the background of the principles of european contract law and the German Civil Code

established in the process and privatization of former state enterprises. It should be noted that the Civil Code notes that the Law may also establish other requirements, which are not subject to limitation [33]. In Ukraine the object of limitation claims is material and non material is out of limitation period. The period of general limitation is 3 year.

\section{Limitation periods in Polish civil code, in Principles of European Contract Law, German Law and in Ukrainian civil code}

\subsection{The beginning of the emergence of the limitation of claims in Polish civil code}

Initially, in European legal systems, including Polish law, the limitation period was determined by various legal occurrences. As a rule, it was the due date of a claim (art. $120 \S 1$ sentence 1 of Polish civil code) [34]. Given its objective nature, the limitation model based on such a solution is called an objective limitation model [35].

The remaining legal events which laid foundations for the emergence of the limitation period in Polish law are the following: - for the claims for the indefinite provision, hypothetically the earliest moment from which a creditor would be able to claim a provision (art. $120 \S 1$ sentence 2 of Polish civil code); - for the claims for renunciation, it is debtor's not applying to a creditor's claim for renunciation (for example, a debtor was obliged not to play the trumpet between 8 a.m. and 1 p.m; therefore if he played, it means that a creditor's claim for renunciation starts from the moment when the debtor disobeyed the rule) (art. $120 \S 2$ of Polish civil code); - for tort claims it is finding out by a creditor about a damage and about a debtor, alternatively occurrence of an objective event - it is the event that caused the damage occurred (art. $442^{1} \S 1$ of Polish civil code).

\subsection{Considerations on harmonization occurrences beginning the limitation in the Principles of European Contract Law - advantages of, so called, subjective limitation model.}

The originators of the limitation period in the Principles of European Contract Law aimed at harmonizing an occurrence, the appearance of which shall cause the beginning of limitation period of every type of claim.

An advantage of such a solution is ensuring legal security of each creditor, which means that the beginning of limitation period of every claim always ensues simultaneously with the occurrence of the same event (it comes to end at the same time).

70 S sciendo Journal of Legal Studies Volume 24 Issue 38/2019 ISSN 2457-9017; Online ISSN 2392-7054.

Web: publicatii.uvvg.ro/index.php/jls. Pages $63-94$ 
Buletsa, S., Zakrzewski, P., (2019)

Limitation of claims in Polish and Ukrainian Civil Code against the background of the principles of european contract law and the German Civil Code

In this light a question arises whether legal occurrence could begin limitation period of every claim.

Hypothetically, it could be the due date of the claim. However, this suggestion is not suitable for claims for damages in tort, as in such a case it is difficult to determine the moment of maturity. Therefore the originators of PECL gave up this solution.

They considered contemplating another option, according to which the limitation period shall occur at the time when a creditor learns about his right to claim. Such a solution occurs in case of claims for damages. The limitation period of such claims begins at the point when an injured party has learnt about a damage and its culprit [36].

An occurrence that spawns the beginning of limitation period has a subjective nature, it depends on the knowledge of a creditor about their right to claim. As long as a creditor does not know about his claim, limitation period does not begin. The limitation model based on the knowledge of a creditor about his right to claim is called a subjective limitation model.

Below we would present the advantages of, the so called, subjective limitation model. Firstly, the greatest advantage is that such a claim shall not lapse unless a creditor knew about his right to claim. Cases when a creditor does not know about his or her right to claim are not very rare [37].

Another advantage of the discussed subjective limitation model is that it enables to reduce the limitation period, however it simultaneously provides a creditor with a high level of protection of his claims.

Since the limitation period concerns exclusively the knowledge of a creditor about his right to claim, the limitation period can be only three years long, which supplies a creditor with a sufficient amount of time to realize his claim. Provided the limitation period begins independently regarding the fact whether a creditor knows about his right to claim or not, the limitation period must be prolongated, by ten years, for instance, so that it can provide a creditor with proper protection, creating a real opportunity to realize his claim.

Despite advantages of the so-called subjective model of limitation, it has not been included in art. 14: 203 passage 1 PECL due to its disadvantages which are discussed thereinafter. According to art. 14:203 passage 1 PECL the general period of prescription commences since the moment when the debtor has to effect performance or, in the case of a right to damages, since the time of the act, initiating the claim. 
Buletsa, S., Zakrzewski, P., (2019)

Limitation of claims in Polish and Ukrainian Civil Code against the background of the principles of european contract law and the German Civil Code

3.3. Occurrences, beginning the limitation period in German law disadvantages of, so called, subjective limitation model.

When we gain a deeper insight into the disadvantages of, the so called, subjective model of limitation in German civil code we can observe that it breaches a rule of a debtor's legal security. The debtor who wants to show that the creditor's claim, addressed to him is time-barred, has to provide a proof as when the creditor learned about his or her right to claim, this is the time since when there has occurred a limitation of the claim. It is complicated because a debtor has to prove the fact that is purely subjective: the creditor's knowledge about their right to claim. If the debtor does not act so, the limitation period will never start and the claim will never lapse. If the legal provisions are based on the solution mentioned above, they also specify that other objective event - rise to a claim, besides the subjective one (a creditor knew about his right to claim), causes the beginning of the limitation period [38].

An example of such a solution is $\S 199$ passage 1 and 4 of German civil code. The standard limitation period commences at the end of the year in which: 1. the claim arose and 2. the obligee obtains knowledge of the circumstances giving rise to the claim and of the identity of the obligor, or would have obtained such knowledge if he had not shown gross negligence. Other claims are subject to limitation regardless of the creditor's knowledge or lack of knowledge about them within the period of 10 years since their inception.

As a result, in German civil code there are two events, involving the start of the limitation period: a basic one of a subjective nature, which is the moment when a creditor learns about their right to claim, and a supplemental one of an objective nature, which is the moment when the claim arose. In addition, there are two limitation periods: subjective - a shorter one, and objective - longer, the course of which depends on various legal events. In German literature there are doubts concerning whether such a limitation model can be called simple and transparent [39]. The so called subjective model, in the mentioned shape, is not perfect, either. It is possible to unify an event which begins the limitation period of the claims only partially. It also complicates the limitation model. Nonetheless, there are proponents of such a solution, suggesting to introduce a double limitation period, giving it a nature of the primary rule to Polish law [40].

According to art. 150 of Polish project of the general section of the civil code the mandatory limitation period is 3 years and this term commences on the day the claimant learned or could easily find out about the existence of the claim and the obligee, but not earlier than: 1) on the due date of the claim, and if the due date of the claim depends on the action taken by the entitled party - on the date the claim becomes due, if the claimant took the action at the earliest possible time, 2) in the

72 sciendo Journal of Legal Studies Volume 24 Issue 38/2019 ISSN 2457-9017; Online ISSN 2392-7054.

Web: publicatii.uvvg.ro/index.php/jls. Pages $63-94$ 
Buletsa, S., Zakrzewski, P., (2019)

Limitation of claims in Polish and Ukrainian Civil Code against the background of the principles of european contract law and the German Civil Code

case of a claim for continuous behavior - on the date on which the obligee failed to comply with the content of the claim.

Article 151 of Polish project of the general section of the civil code introduces the so-called final limitation period. The claim is time-barred ten years from the date of maturity at the latest, and if due depends on the action taken by the entitled - ten years after the date of the claim at the latest. The claim for compensation for damages is time-barred ten years from the date of the event causing the damage at the latest. However, this does not concern a claim for personal injury.

\subsection{Occurrences beginning the limitation period in Ukrainian civil code}

The restriction manifests itself in the connection "purpose - means - result" and directly affects the possibility of exercising legitimate interest and the acquisition of subjective rights. It is manifested in imperative directions concerning the limitation of the implementation of freedom and subjective law in certain legal relationships. According to the Article 13 of Ukrainian Civil Code exercising his or her rights a person is obliged to refrain from acts that could violate the rights of others, harm the environment or cultural heritage, the actions of a person committed with the intention of causing harm to another person, as well as abuse right in other forms. Exercising civil rights, a person must observe the moral principles of society. Manifestations of restrictions of civil rights are the provision of competition, equal position in commodity markets, the development of fair competition, etc. In case of violation of civil rights and non-fulfillment of civil obligations in Ukraine civil liability takes place and a person may apply to the court for the protection of his violated rights.

In article 256 of Ukrainian Civil Code we find the concept of Limitation of Action - shall be a period within which a person may file a claim for protection of his/her civil right or interest. The main attention is drawn to the fact that the limitation period is a term, but on its time limit. We believe this definition is not entirely successful because it contradicts Part 2 of the Art. 267 of the Civil Code of Ukraine, according to which "a statement on the protection of civil law or interest must be adopted by the court for consideration regardless of the expiry of the limitation period". This means that the person whose right is violated may apply for his defense to the court at any time, regardless of whether he has ceded, or no limitation period.

Ukrainian Civil Code lays foundations for concluding that the term "appeal" ("a person may apply") has purely materially legal content. This corresponds to the understanding of the limitation period in Ukrainian civil law as the institution of substantive law. In the procedural sense, the expiry of the limitation period does 
Buletsa, S., Zakrzewski, P., (2019)

Limitation of claims in Polish and Ukrainian Civil Code against the background of the principles of european contract law and the German Civil Code

not preclude an application to a court to bring an action in defense of a violated right or interest.

Accordingly to Part 5 of Art. 324 Commercial Code [41] a claim for compensation to the customer of losses caused by project flaws can be declared within ten years, and if losses to the customer were caused by illegal actions of the contractor which led to destruction, accidents, collisions - within thirty years from the date of acceptance of the constructed object. In case the statute of limitations is a time limit for appealing to a court (Article 256 of the Civil Code), then the time period during which a claim is possible (Part 5 of Article 324 of the Commercial Code), shall be qualified as a limitation period. Part 3 of Art. 322 of the Commercial Code notes that the limitation period for claims arising from inadequate quality of works under a contract for capital construction is determined from the date of acceptance of work by the customer and is as follows: thirty years - in respect of compensation for losses incurred by the contractor to the wrongful acts of the contractor that resulted in destruction or accidents, that is, the Commercial Code of Ukraine provides for a maximum period of limitation. The Civil Code has a three-year limitation period.

Notably, according to Part 6 of Article 232 of the Commercial Code of Ukraine, the calculation of penalties for delay in the performance of the obligation, unless otherwise provided by law or agreement, ceases in six months after the date when the obligation was to be fulfilled. According to point 1 of Part 2 of Article 258 of Ukrainian Civil Code with the requirement to collect fines, a person may apply to the court within one year from the moment of on-fulfillment of the obligation (Resolution of the Supreme Court of Ukraine dated April 27, 2012 No. 3-27g12) [42].

Part 6 of Article 261 of Ukrainian Civil Code stipulates that for recourse proceedings, the limitation period shall begin from the day the principal obligation is performed. In such circumstances, since the plaintiff has fulfilled his obligations under a voluntary insurance contract, he has the right to file a recourse action in court [43].

Looking closer at a court of appeals, a party to a dispute may declare the limitation period expiring, which proves impossibility to submit a corresponding application in the court of first instance, in particular, if the party concerned has not been duly informed about the time and place of the proceedings by the local commercial court. The said application may also be made in the course of a new consideration of the case, which is carried out after the cancellation of the court decision on the results of its cassation review.

It is necessary to emphasize that an application for expiration of a limitation period, made by any other person (including a party to the trial, including a public

74 S sciendo Journal of Legal Studies Volume 24 Issue 38/2019 ISSN 2457-9017; Online ISSN 2392-7054.

Web: publicatii.uvvg.ro/index.php/jls. Pages 63 - 94 
Buletsa, S., Zakrzewski, P., (2019)

Limitation of claims in Polish and Ukrainian Civil Code against the background of the principles of european contract law and the German Civil Code

prosecutor who is not a party to the case), other than the party to the dispute, is not a sufficient background for the court to use the limitation period. In case of two or more defendants, the court may refuse to accept a claim in the presence of the said application only one of them, because the statute of limitation is set by law for the plaintiff in the case as a term within which he may apply to the court. However, in 2017, the Supreme Court of Ukraine concluded that the law does not authorize the prosecutor to raise the issue of renewal of the limitation period in the absence of such a petition from the person in whose interests the prosecutor appeals to the court. The split of the general limitation period before filing a claim, the absence of a petition of the plaintiff for the renewal of such a term, as well as the statement of the defendant on the application of the limitation period, is the reason for the refusal of the claim [44], which contradicts the opinion of the Supreme Court since 2013, which states that the relevant initiative may come and from other participants in the trial, in particular, the prosecutor who is not a party to the case [45]. I believe that the opinion of the Armed Forces of Ukraine from 2017 is correct, it is necessary that the prosecutor does not decide on the need to renew the limitation period, but the party himself declared this or gave the appropriate powers of the prosecutor.

The law does not establish requirements for the form of statement of the party on the expiration of the limitation period. Therefore, it may be set out in the claim form or as a separate application, written or oral. The judge shall not, on his / her own initiative, indicate the expiration of the limitation period. If the interested party refers to the expiration of such a limitation, the judge has the right to invite each of the parties to submit relevant evidence on the matter included in the preparation of the case for consideration.

The limitation period applies only if there is a violation of the right of a person. Consequently, before applying the limitation period, the court should find out and indicate in the court decision whether there was breach of the law or the lawprotected interest of the plaintiff, whose protection he appealed to the court. In case when such a right or interest is not violated, the court refuses to sue on grounds of its groundlessness. In case it is established that the interest of the person was actually violated or protected by law, with the limitation period expiring and the statement was made by the other party, the court refuses to sue due to the expiry of the limitation period - in the absence of the valid reasons given by the plaintiff omission.

In fact, the renewal of the statute of limitations is the expression of the will of the court aimed at protecting the rights of the person violated, after the expiration of the limitation period in the presence of valid reasons. Regarding the individual, the latter can be documented by a serious illness, prolonged stay outside the place of 
Buletsa, S., Zakrzewski, P., (2019)

Limitation of claims in Polish and Ukrainian Civil Code against the background of the principles of european contract law and the German Civil Code

their permanent residence (for example, abroad), etc. With regard to the enterprise, these circumstances can not be taken into account by the court because in the absence (including for good reason) of the person who represents it in court proceedings, the relevant institution is not deprived of the right and ability to provide involving another person in such a process; the absence of this possibility is subject to general reasons. The law does not determine on whose initiative the court recognizes the reasons for the expiry of the statute of limitations to be viable. As a rule, this is carried out on the request of the plaintiff with indication of the relevant arguments and the submission of appropriate and admissible evidence [46]. The point is that the legislator did not foresee a repetition or extension of the limitation period, as it was established in case of its interruption, and did not establish an additional term for protection of the violated right in the presence of valid reasons. Accordingly, a person is not required to file a new claim after the court recognizes the valid reasons for the refusal of the limitation period, and the protection of the plaintiff's right is carried out directly within the limits of the proceedings. This is reflected in Part 5 of Article 267 of the Civil Code of Ukraine: if the court finds good reasons for passing the limitation period, the violated right is subject to protection. Consequently, there is virtually no renewal of the limitation period, the court recognizes the right to protection of the plaintiff and does not apply the effects of expiration of the limitation period.

Concurrently, paragraph 4 of the Resolution of the Plenum of the Supreme Court of Ukraine "On the practice of consideration by the courts of labor disputes" of November 6, 1992, No. 9 [47] stipulates that the terms of appeal to the court established by Articles 228, 233 of the Labor Code [48] apply regardless of the application of the parties. No changes were made to this provision until today. But this approach is contrary to Art. 267 of Ukrainian Civil Code, according to which the limitation period applies only on the application of the party to the dispute. Unlike a civil process where filing a lawsuit with a violation of the statute of limitations does not exclude the court's duty to consider the merits of the case, in the administrative process of establishing the fact that the time-limit for applying to the court is suspended, it is grounds for leaving the application without consideration at any stage of the proceeding [49].

It is worth noting that in Part 1 of Art. 261 of the Civil Code the general rule is formulated according to which the limitation period commences from the day when the person became aware of the violation of his right. If it is impossible to establish a day when a person became aware about it, or there is evidence that the person did not know about a violation of the law, although under the present circumstances he should have been aware of it, the limitation period starts from the day when the person should have been informed about his or her violated rights A comparative

76 Sciendo Journal of Legal Studies Volume 24 Issue 38/2019 ISSN 2457-9017; Online ISSN 2392-7054.

Web: publicatii.uvvg.ro/index.php/jls. Pages $63-94$ 
Buletsa, S., Zakrzewski, P., (2019)

Limitation of claims in Polish and Ukrainian Civil Code against the background of the principles of european contract law and the German Civil Code

analysis of the terms "learned" and "could", contained in Article 261 of Ukrainian Civil Code, gives grounds for the conclusion that the presumption of the possibility and duty of a person to know about the state of his property rights, and therefore to prove the fact through which the plaintiff did not know about violation of his civil law and for this reason did not apply for his defense in court, are not enough. The plaintiff must also prove that he could not find out the violation of his civil law, which also results from the general rule established by Article 60 of Ukrainian Civil Code, on the binding obligation of the party to submit a dispute in the circumstances on which it refers as a basis for its claims and objections. The defendant, on the contrary, must prove that information about the violation could be obtained earlier [50].

There occur cases when a person has learned of a violation of his or her right, but does not know which subject has committed a violation. In this case it is assumed that the validity of the limitation period begins from the day when the controlled person has learned of the subject that violated his or her right.

On the other hand, in cases where the obligation specifies the term of execution, the limitation period begins with the expiration of the term of execution, at the very time of the expiration of the term of execution, the controlling person did not know and could not know about the violation of the right. Therefore, the sale obligation is deemed to be fulfilled by the seller at the time of the delivery of the alienated goods to the carrier (Part 2 of Article 664 of the Civil Code).

Focusing on the proceding of the limitation period in respect of claims for recognition of invalid acts, we clearly see that it is calculated not from the moment the transaction was made, but from the day the person knew or could have been aware of the violation of his right or of the person who violated it. Additionally, the Central Committee of Ukraine established exceptions to this rule regarding certain requirements related to the recognition of transactions invalid (parts 2, 3 of Article 261 of this Code).

To such understanding of the norms of Art. 261 of the Central Committee reduces the legal conclusion of the SCU, made during the consideration of the case No. 675 tss 15 in the resolution of February 3, 2016.

As revealed in the course of the analysis, local courts have had problems determining the commencement of the limitation period while considering cases on the recognition of transactions as invalid.

For instance, the decision of the Taraschansky District Court of the Kyiv region dated November 28, 2014, satisfies the claims in a civil case under the lawsuit Z.A.V. to LLC "T." for the invalidation of the land lease agreement.

As is apparent from the case file, satisfying the claim by the court of first instance indicated that the reference of the defendant's representative to the applicant's 
Buletsa, S., Zakrzewski, P., (2019)

Limitation of claims in Polish and Ukrainian Civil Code against the background of the principles of european contract law and the German Civil Code

omission of the limitation period can not be considered, since, in accordance with

Part 5 of Art. 261 of the Central Committee for obligations with a specified period of execution, the limitation period begins with the expiration of the term of execution. In accordance with the lease of land, taking into account the moment of its state registration on September 29, 2009 as the beginning of its operation, the term of this contract expires on September 29, 2019.

By order of the Court of Appeal of Kyiv region dated January 27, 2015, the decision of the Tarashchansky District Court of Kyiv Oblast has been cancelled, a new decision has been passed, which was rejected in satisfaction of the claim.

Court of Appeal came to the conclusion that Z.A.I. appealed to the court with the present claim in October 2014, that is, with the omission of the established article 257 of the Central Committee of the term of limitation, since the violation of her rights was recognized in September 2009. The plaintiff did not provide evidence of the gravity of the reasons for passing the limitation period.

Z.A.I. could find out about the violation of his right in accordance with the subject of claims since the conclusion of the disputed land lease agreement, that is, since September 17, 2009. As established by the court and recognized by the parties, the contract of lease of the land plot is disputed on September 17, 2009 on behalf of Z.A.I. was signed by her husband - Z.V.I. Impressions of witnesses Z.V.I., P.V.R. testified that the plaintiff was aware of the conclusion of a land lease contract and the signing on behalf of her husband since its conclusion, that is, from September 17,2009 [51].

The legal position of the Supreme Court of Ukraine in the case No. 6-522ts17 is interesting: According to Article 629 of the Civil Code of Ukraine, the contract is binding for the parties to execute. In accordance with Article 1054 of the Civil Code of Ukraine, under a loan agreement, a bank or other financial institution (the lender) undertakes to provide loan to the borrower in the amounts and on terms established by the contract, and the borrower undertakes to repay the loan and pay interest (part one of the article 1048 of this Code).

The consequences of delinquency by the borrower of repayment of a loan are defined in part two of Article 1050 of Ukrainian Civil Code. In case the contract establishes the obligation of the borrower to repay the loan by installments, in case of delay of the return of the next part, the lender has the right to demand early repayment of the remaining part of the loan and payment of interest due to him in accordance with Article 1048 of this Code.

Herein, the proceeding of the limitation period on the creditor's claims arising from the debtor's violation of the terms of the contract (schedule of repayment of the loan) on repayment of the debt by monthly payments begins with respect to each

78 S sciendo Journal of Legal Studies Volume 24 Issue 38/2019 ISSN 2457-9017; Online ISSN 2392-7054.

Web: publicatii.uvvg.ro/index.php/jls. Pages $63-94$ 
Buletsa, S., Zakrzewski, P., (2019)

Limitation of claims in Polish and Ukrainian Civil Code against the background of the principles of european contract law and the German Civil Code

separate part from the date when the violation occurred. The limitation period in such cases is calculated separately for each overdue payment [52].

When the term or period of performance of the obligation is not determined or determined by the moment of execution of the request, the creditor has the right to demand fulfillment of the obligation at any time. At the same time, the debtor receives a grace period of seven days. Since the expiration of this term, the limitation period begins.

In accordance with recourse requirements, the limitation period is attributed to deduct from the time the principal obligation is performed. In judicial practice, regressive requirements are sometimes understood too broadly. Certainly, there were court decisions, in which the recourse called claims for recovery from debtors of losses caused by payment by the creditor, who is the debtor in another obligation of a penalty in favor of the creditor in this obligation. Meanwhile, the law does not justify the use of the term "recourse" in such cases. The recourse requirement is not explicitly defined in the Civil Code, but from Part 2 of Art. 124, part 1 of Art. 198, Part 1 of Art. 544, part 2 of Art. 557, part 1, article. 569 CC, paragraph of the second part of the 4th c. 619 of the Civil Code, Part 1 of Art. 1191 of the Civil Code it follows that a regressive (reverse) claim is made in the case of fulfillment by one person of an obligation that another person must perform. On the other hand, the requirement of the insurer, who paid the insurance indemnity under the contract of property insurance, to the person responsible for the damage caused, is not called a regressive or reverse in Art. 993 of the Civil Code, not in Art. 27 of the Law "On Insurance" [53].

It is possible to establish exceptions to the rules on the commencement of the limitation period. They may be provided by the Civil Code and laws. This rule is Part 7 of Art. 261 The Central Committee does not exclude the action of a special rule of Part 3 of Art. 925 of the Central Committee, according to which not only the transport codes (they are legislative acts, that is, they have the legal force of laws), but also transport charters (they are by-laws) may determine the moment of the beginning of the validity of the limitation period of one year, established for the requirements arising from the contract of carriage of cargo, mail. The beginning of the validity of the limitation period depends both on the object of the offense and on the person of the creditor. Such a connection with the lender is due to the fact that the limitation period starts from the date of reaching its age. Simultaneouslly, the protection of the rights of minors is possible and prior to the expiry of the limitation period, which is carried out at the request of their legal representatives. In other cases, the limitation period should be counted in accordance with the rules of art. 680 of the Civil Code from the day of detection of shortcomings of the goods sold, provided that the deficiencies were identified in the following terms: 
Buletsa, S., Zakrzewski, P., (2019)

Limitation of claims in Polish and Ukrainian Civil Code against the background of the principles of european contract law and the German Civil Code

1) if the product does not have a warranty period or expiry date - within a reasonable time, but in any case within two years after the transfer of the goods to the buyer. Two years is a deadline if the longer term is not set by law. But in resolving the dispute, if this deadline is not exceeded, the court should apply a "reasonable time", which may be many times shorter than the specified time. If the goods are transported or sent to the buyer by post, these terms are calculated from the date of receipt of the goods at the place of destination;

2 ) in the case of immovable property for which a warranty period or expiry date has not been established, within a reasonable time, but within three years from the day the property is transferred to the buyer. If the day of transfer of immovable property cannot be established, or if the buyer owns immovable property before the conclusion of the contract, this period is calculated from the date of conclusion of the contract;

3) within the warranty period or expiration date, if the product has a warranty period or expiry date [54].

\subsection{The lack of harmonization of occurrences which begin the limitation period in Principles of European Contract Law - another variant of subjective model}

Taking into account the disadvantages mentioned above, in Principles of European Contract Law another variant was adopted. It is, so called, a model of subjective limitation. It has its advantages, and does not have drawbacks mentioned earlier.

In Principles of European Contract Law there is not a demand of harmonization of events which begin the limitation period of the claims. These events are still diversified.

The beginning of the limitation period is basically designated by an objective event. It begins from the moment when a debtor is to provide a provision (and a provision is of the due date). The limitation period for claims for damages starts from the moment a debtor begins his or her activity on which a claim is based (art. 14:203 passage 1 PECL).

In case of the claims granted by a judgment or a judicial decision of the arbitration court, as well as those resulting from a document with enforceability clause, the limitation period starts on the day when a judgment or settlement will obtain legitimacy, and the document will become actionable. However, not earlier than before enforceability of claims (art.14:203 passage 3 PECL). On the other hand, the course of claims for continuous operations or failure begins from the moment of breaching the obligations to perform them (art.14:203 passage 2 PECL).

The limitation model in the Principles of European Contract Law has, however, so called a subjective nature [55]. The subjective model of limitation makes the

80 Sciendo Journal of Legal Studies Volume 24 Issue 38/2019 ISSN 2457-9017; Online ISSN 2392-7054.

Web: publicatii.uvvg.ro/index.php/jls. Pages $63-94$ 
Buletsa, S., Zakrzewski, P., (2019)

Limitation of claims in Polish and Ukrainian Civil Code against the background of the principles of european contract law and the German Civil Code

limitation period dependent on a creditor's knowledge about their right to claim. There was assumed that a creditor's lack of knowledge about his or her right to claim causes that the beginning of limitation shall be suspended for the time in which a creditor had no knowledge about his or her claim.

The version of a subjective limitation model has been included in art. 14:301 of PECL, which treats a debtor's lack of knowledge as a cause of suspension of the limitation period: ,The running of the period of limitation is suspended as long as the creditor does not know of, and could not reasonably know of: (a) the identity of the debtor; or (b) the facts giving rise to the claim including, in the case of a right to damages, the type of damage."

\section{The effects of the expiry of the limitation periods}

The effects of the expiry of the limitation periods consist in possibility of refusing by the beholden to perform (art. 14:501 passage 1 PECL), because he or she is entitled to the limitation plea. One cannot demand reimbursement of the provision which has been met, relying on the limitation of a claim. Lapsed claim is regarded as legally existing. Such a solution occurs in the German and Ukrainian Civil Code as well as in the Principles of European Contract Law (art. $117 \S 2$ of Polish civil code, $\S 214$ of German civil code, art. 267 part 4 of Ukrainian civil code).

Amendment to the Polish civil code, which was brought into force on 9th July 2018, introduced, among others, specific legal regulation that is art. $117 \S 2^{1}$ of Polish civil code. It projects that the effect of lapse of limitation is the period of limitation for entrepreneur's claims against a consumer. As a result, there appears ex lege transition of an actionable claim into unactionable ones (into imperfect, natural obligation) that is the one which cannot be executed compulsorily. This dubious solution is supposed to be justified by the fact that a consumer is the weaker part of legal relation and not always realizes their right to defence of limitation. It does not, however, mean that court ex officio will be providing evidence for existence or non-existence of the fact of lapse of limitation (the rule of contradictoriness), which will restrict viable significance of art. $117 \S 2^{1}$ of Polish civil code.

The solution from art. $117 \S 2^{1}$ of Polish civil code is, however, limited in the new art. $117^{1} \S 1$ of Polish civil code. It allows court, in exceptional circumstances and after taking into account rights of both parties, not to include lapse of limitation directed against an entrepreneur, which basically occurs ex lege if legitimacy considerations require it. Without taking into account consequences of limitation of claims against a consumer, court should consider the length of the limitation period as well as the length of the period from lapse of limitation to the moment when the claim is enforced, the nature of circumstances which caused not pursuing the claim 
Buletsa, S., Zakrzewski, P., (2019)

Limitation of claims in Polish and Ukrainian Civil Code against the background of the principles of european contract law and the German Civil Code

by the eligible party, and in particular the debtor's behaviour (art. $117^{1} \S 2$ od Polish civil code).

In the Principles of European Contract Law the effects of the expiry of the limitation period of the main claim concern side claims as well. Limitation of claims for interest and other side provisions follows up no later than the time of limitation of the main claim (art. 14:502 PECL). After expiring of the limitation period offsetting of the lapsed claim is also possible, as long as the beholden hasn't raised a plea of limitation before, or will not do it within two months since the time of receiving a statement of deduction (art. 14:503 PECL). The same solution is adopted in art. 266 of Ukrainian civil code.

In the Polish Civil Code rule form art. 14:502 PECL is not explicitly provided, yet is accepted on the basis of interpretation. The Polish Supreme Court referred to the article 14:502 PECL: "The limitation period laid down in article 118 of civil code for the claims for periodic provisions shall apply to claims for interest for the delay even when the main claim is lapsed within the time limit referred to in article 554 of Polish civil code. A claim for interest for the delay shall lapse, however, at the latest upon the limitation of the main claim". In the literature there has been raised a need to introduce to a civil code a rule, which will determine that the limitation of the main claim shall cause the limitation of claims for the provision of accessory [56].

In Polish civil code the receivable debt barred by limitation may be set-off if at the moment when the set-off became possible it has not been barred yet (art. 502 of Polish civil code).

\section{Conventional regulation of length of limitation periods}

Conventional regulation of the limitation, which allows suspending and reducing of limitation periods, is allowed in the Principles of European Contract Law (art. 14:601 PECL). The limitation period, however, cannot be shorter than a year or longer than thirty years since the beginning of the limitation period specified in art. 14:203 PECL.

Regarding the change in the limitation period, it is fairly liberal in respect of contracts for changing the statute of limitations Principles of European contract law and Principles of UNIDROIT. According to Clause 1 of Art. 14: 601 Principles of European contract law, rules on the limitation of the right of claim can be freely modified by agreement of the parties, in particular by increasing or reducing the limitation period of the right to claim. The only limitation of such an approach in accordance with paragraph 2 of the said article is the prohibition of the reduction of the limitation period to a period of less than one year and an increase in such a period to a period of more than 30 years from the moment of its beginning. The

82 sciendo Journal of Legal Studies Volume 24 Issue 38/2019 ISSN 2457-9017; Online ISSN 2392-7054.

Web: publicatii.uvvg.ro/index.php/jls. Pages $63-94$ 
Buletsa, S., Zakrzewski, P., (2019)

Limitation of claims in Polish and Ukrainian Civil Code against the background of the principles of european contract law and the German Civil Code

provisions of the DCFR on changing the limitation period under the agreement between the parties (clauses 1, 2 of Article 111.-7: 601), as a continuation of the Principles of European Contract Law, establish the same conditions for increasing and reducing the limitation period on the basis of the contract (clauses 1, 2 of item 14: 601). Soft law, regulating the issues of contractual formation of limitation periods, determines the maximum and minimum terms. The maximum term of thirty years is defined in the Principles of European Contract Law, DCFR, CESL (General European Sales Law), while the UNIDROIT Principles define such a term of 15 years. The minimum limitation period of one year is set in all of these acts.

Agreements on limitation periods should be considered as an effective opportunity to settle disputes between the parties and an additional mechanism for protecting both the debtor and the creditor. One should positively evaluate the current world tendency to reduce the general limitation period and the imperative regulation of this legal institution, which is expressed, among other things, in the assumption by an increasing number of law and order (including European) of the possibility of changing the general limitation period by agreement of the parties, especially in relations between business entities. However, in Ukraine it is only allowed to increase the limitation period, and not reduce it.

Mandatory nature of legal rules concerning limitation in Polish civil code, which is to guarantee protection for the weaker party, excludes the conventional regulation of length of limitation periods (art. 119 of Polish civil code). It is in a contrary to a principle of autonomy.

Whereas in the German civil code it is possible to contractually reduce or extend limitation periods ( $\$ 202$ of German civil code) [57].

It should be noted that according to Art. $259 \mathrm{CC}$ sentencing, established by law, may be suspended by agreement of the parties. An agreement on increasing the limitation period shall be in writing. The statute of limitations, set by law, cannot be reduced by agreement of the parties. The condition for increasing the limitation period may be placed both in the contract of sale, supply, provision of services, etc., as well as in a separate document or in letters, telegrams, and other documents exchanged between the parties and which must unambiguously indicate the achievement of an agreement parties to extend the limitation period.

\section{Conclusions}

The provisions on statute of limitations, adopted relatively recently in the German and Ukrainian civil codes (see also the Polish project of the general section of the civil code), considerably fulfill the postulate of a uniform, transparent and simplified limitation model. In these regulations legislators aimed at unifying events that start the limitation period, linking the its beginning to a subjective 
Buletsa, S., Zakrzewski, P., (2019)

Limitation of claims in Polish and Ukrainian Civil Code against the background of the principles of european contract law and the German Civil Code

event, as well, whereby the duration of a limitation period shall begin from the day when a person learned or could learn about violation of his/her right or about a person that violated the right. (Article 261 (1) of the Ukrainian Civil Code, see Article 150 of Polish project of the general section of the civil code). In the German Civil Code, the mentioned moment of commencement of the limitation period is supplemented with an objective event, such as the end of the year in which the claim arose (see $\S 199$ of the German Civil Code).

These solutions are beneficial for the creditor and protect his interests better. However, they have some drawbacks and either may pose difficulties in determining objectively when the limitation period has begun, as in the case of art. 261 par. 1 of the Ukrainian Civil Code and art. 150 of Polish academic project of the general section of the civil code, or make the events that commence the limitation period remain varied, as in $\S 199$ of the German Civil Code. The solution appearing in art. 14: 301 PECL, which provides that the lack of knowledge of the creditor about his claim is the reason for suspension of the limitation period, is devoided of these defects. On the other hand, events starting the limitation period remain varied, as was the case with earlier regulations, e.g. the Polish Civil Code. Due to the advantages of art. 14: 301 PECL an introduction of such a solution (Article 14: 301 PECL) to the Polish and Ukrainian legal system is intentional.

Given that in the German and Ukrainian Civil Code, as well as in the Polish project of the general section of the civil code, the beginning of the limitation period has been related to the subjective event, which is the creditor's knowledge of his claim, it was possible to reduce the period of limitation without the danger of violating the protected in the constitutions national property rights. As the optimal the authors allow the three-year limitation period due to the acceleration of the pace of life

National legislators interpret the issue of prescription differently. In Polish and Ukrainian law the subject of prescription is only property claims, which is the result of the assumption of enhanced protection of non-property goods. This solution seems to be appropriate. It is different in German law and the Principles of European Contract Law, where property and non-property claims are subject to a statute of limitations. In each of the civil codes discussed, however, there are specific claims that have different lengths of limitation periods. The catalogue of these claims is diverse and depends on the legal tradition of a given country, with attending economic and social conditions. It illustrates, however, that the harmonization and simplification of the regulation of the limitation period has not been fully achieved.

In national orders the effects of expiration of the limitation period were basically equally regulated, namely they were considered merely at the request of the debtor. The lapse of the limitation period, the application of which is declared by the party

84 sciendo Journal of Legal Studies Volume 24 Issue 38/2019 ISSN 2457-9017; Online ISSN 2392-7054.

Web: publicatii.uvvg.ro/index.php/jls. Pages $63-94$ 
Buletsa, S., Zakrzewski, P., (2019)

Limitation of claims in Polish and Ukrainian Civil Code against the background of the principles of european contract law and the German Civil Code

to the dispute, is the reason for the refusal of the claim. If the court acknowledges the valid reasons for passing the limitation period, the breached right shall be protected. The exception to this rule recently has appeared in Polish law, where the limitation of claim against a consumer occurs in virtue of law, although court may depart from this consequence in exceptional cases, after considering rights of both parties, if reasons of equity require it. These solutions do not simplify the model of limitation, giving it, however, a casuistic form. Moreover, it should be expected that they lead to complicating and lengthening judicial proceedings.

The most liberal solution in the area of contractual regulation of limitation is provided in the German Civil Code, which allows to shorten and prolong the statutory limitation period, whereas the most severe is provided for in the Polish Civil Code, prohibiting it altogether. An indirect solution has been adopted by the Ukrainian Civil Code, which allows only the extension of the statutory limitation period. These different legislative solutions demonstrate that the national legislators are partially different in their view of the reasons justifying the statute of limitations. Some give greater importance to legal security, which results in the inadmissibility of contractual regulation of limitation periods, and others to the marketing needs, which leads to opposite conclusions. It seems that the German solution suits the needs of trade better, but it can be debated in the consumer turnover.

Newer prescription regulations, to which the German and Ukrainian ones belong, are largely similar to each other. The same can be said about the Polish academic project of the general section of the civil code. It should be assessed positively, since it facilitates the future harmonization of European civil law, which in turn is advisable for economic and social reasons. It also seems that the Principles of European Contract Law, whose content the authors assess positively, have had a significant impact on teaching of civil law, as well as on national legislators.

\section{Acknowledgements}

The author thanks the anonymous reviewers and editor for their valuable contribution.

\section{Funding}

This research received no specific grant from any funding agency in the public, commercial, or not - for - profit sectors.

\section{Author Contributions}

The entire article was written by Sibilla Buletsa and Piotr Zakrzewski. 
Buletsa, S., Zakrzewski, P., (2019)

Limitation of claims in Polish and Ukrainian Civil Code against the background of the principles of european contract law and the German Civil Code

\section{Disclosure Statement}

The authors have not any competing financial, professional, or personal interests from other parties.

\section{References}

1. Academic Project of Civil Law. URL: http://www.projektkc.uj.edu.pl/ (date of access: 2 April 2019).

2. Bürgerliches Gesetzbuch, in der Fassung der Bekanntmachung vom 02.01.2002 (Bundesgesetzblatt, I S. 42, ber. Seite. 2909, 2003 Seite. 738) zuletzt geändert durch Gesetz vom 06.06.2017 (Bundesgesetzblatt, I S. 1495).

3. Civil Code of Ukraine from 16.01.2003 № 435-IV. Reports of the Supreme Rada of Ukraine. 2003. № 40-44. ст.356

4. German Civil Code https://www.gesetze-iminternet.de/englisch_bgb/englisch_bgb.html\#p0572 (date of access: 2 April 2019).

5. Heinz-Peter Mansel, in R. Strüner (eds.) "Jauering Bürgerliches Gesetzbuch mit Rom-I, Rom-II, Rom-III-VO, EG-UntVO/HuntPrpt und EuErbVO. Komentar", (C.H. Beck, München, 2015), 161.

6. Jacek Zrałek, Przedawnienie w międzynarodowym obrocie handlowym, Zakamycze, Kraków, 2005, pp. 13-38, 56-68.

7. Jacek Zrałek, Przedawnienie roszczeń $\mathrm{w}$ polskim prawie cywilnym - szkic porównawczy, in Leszek Ogiegło, Wojciech Popiołek, Maciej Szpunar (eds), Rozprawy prawnicze. Księga pamiątkowa Profesora Maksymiliana Pazdana, Zakamycze, Poznań, 2005, p. 83.

8. Jürgen Ellenberger, in "Palandt. Bürgerliches Gesetzbuch“, C. H. Beck, München, 2010, pp. 219-220.

9. Piotr Zakrzewski, Przedawnienie w zasadach europejskiego prawa umów z perspektywy polskiej, Roczniki Nauk Prawnych, 2006, 16 (2), p. 78.

10. Polish civil code. Articles P442, 449/8. URL:

http://prawo.sejm.gov.pl/isap.nsf/download.xsp/WDU19640160093/U/D19640093Lj.pdf (2 April 2019).

11. Reinhard Zimmermann, „... ut sit finis litum” Grundlinien eines modernen Verjährungsrechts auf rechtsvergleichender Grundlage", (18) Juristen Zeitung, (2000), 862; Piotr Zakrzewski, op. cit., note 10, 82-83.

12. Reinhard Zimmermann, Detlef Leenen, H. P. Mansel, W. Ernst, "Finis Litum? Zum Verjährungsrechts nach dem Regirungsentwurf eines Schuldrechtsmodernisierungsgesetze", (13) Juristen Zeitung (2001), 687; Reinhard Zimmermann, op. cit., note 33, 862.

13. Resolution of the 7 Supreme Court Judges of January 26, 2005, III CZP, 42/04, Orzecznictwo Sądów Polskich, 2006, z. 3, s. 3.

14. Resolution of the Supreme Court of Ukraine dated March 27, 2012, No. 3-20h12.

15. Roman Trzaskowski, Roszczenia związane z prowadzeniem działalności gospodarczej w rozumieniu art. 118 k.c., Przeglad Sadowy, 2006, 2, pp. 3-15; Piotr Machnikowski,

86 sciendo Journal of Legal Studies Volume 24 Issue 38/2019

ISSN 2457-9017; Online ISSN 2392-7054.

Web: publicatii.uvvg.ro/index.php/jls. Pages $63-94$ 
Buletsa, S., Zakrzewski, P., (2019)

Limitation of claims in Polish and Ukrainian Civil Code against the background of the principles of european contract law and the German Civil Code

Przedawnienie roszczeń, in Edward Gniewek, Piotr Machnikowski (eds.). Kodeks cywilny. Komentarz, C. H. Beck, Warszawa, 2016, p. 282; wyrok SN z 8 kwietnia 2011 r., II CSK 434/10, LEX nr 1027169.

16. Stubbings and Others v. The United Kingdom, no. 22083/93, § 51, ECHR, 1996-IV. HUDOC. URL: http://hudoc.echr.coe.int/eng?i=001-58079 (2 April 2019).

17. Suprem Court of Ukraine. 05.04.2017. № 6-522-цс-17) URL: http://protokol.com.ua/ua/vsu_perebig_pozovnoi_davnosti_za_vimogami_kreditora_yaki_v iplivayut_z_porushennya_borgnikom_umov_dogovoru_pro_pogashennya_borgu_chastina mipochinaetsya_stosovno_kognoi_okremoi_chastini_(vsu_vid_05_04_2017_6_522tss17)/ (date of access: 2 April 2019).

18. Sylwester Wójcik, Przedawnienie w prawie cywilnym po zmianie kodeksu cywilnego ustawą z 28 lipca 1990 r., Przegląd Sądowy, 1991, 1-2, p. 42.

19. Tekst jednolity Dz. U. z 2017 r. poz. 201, 648, 768.

20. The Principles of European Contracts Law 2002 (Parts I, II, III). European Union. URL: http://www.jus.uio.no/lm//eu.contract.principles.parts.1.to.3.2002/sisu_manifest.html (date of access: 18 June 2018).

21. The Project of Civil Law Codification Commission http://www.projektkc.uj.edu.pl/index.php/projekty (date of access: 2 April 2019).

22. Uchwała Sądu Najwyższego z 18 czerwca 2015 r., III CZP 31/15, (6, pozycja 67), Orzecznictwo Sądu Najwyższego Izba Cywilna”, (2016); Piotr Zakrzewski Komentarz do uchwały Sądu Najwyższego z 18 czerwca 2015 r., III CZP 31/15, Rocznik orzecznictwa $i$ piśmiennictwa z zakresu prawa spółdzielczego, 2017, VII, p. 195; Piotr Zakrzewski, Przedawnienie roszczeń, in: Magdalena Habdas, Mariusz Fras (eds.), Kodeks cywilny. Komentarz, t. I. Część ogólna (art. 1-125), Wolters Kluwer, Warszawa, 2018, p. 966.

23. Ustawa z dnia 23 kwietnia 1964 r. - Kodeks cywilny, tj. Dziennik Ustaw, 2017, pozycja 459.

24. Verdict of the polish Supreme Court of February 15, 2001, II CZN 390/00, “Orzecznictwo Sądów Polskich", (10) 2001, pozycja. 140, 477.

25. Аналіз судової практики внаслідок застосування судами роз'яснень, викладених у Постанові Пленуму ВСУ «Про судову практику розгляду цивільних справ про визнання правочинів недійсними». URL: http://protokol.com.ua/ru/vssu_analiz_sudovoi_praktiki_pri_zastosuvanni_sudami_roz_yas nen_vikladenih_u_post_plenumu_vsu/ (date of access: 2 April 2019).

26. Верховний Суд України від 16 листопада 2016 р. у справі 6-2469-цс-16. URL: http://protokol.com.ua/ua/vsu_ne_tilki_ne_znav_a_i_ne_mig_dovidatis_obov_yazkova_um ova_dlya_ponovlennya_stroku_pozovnoi_davnosti/ (date of access: 2 April 2019).

27. Господарський кодекс України від 16.01.2003 p. № 436-IV.

URL: http://zakon0.rada.gov.ua/laws/show/436-15 (дата звернення: 14.07.2019).

28. Гуйван Петро, Теоретичні питання співвідношення присічних строків та строків позовної давності, Наџіональний юридичний журнал: теорія і практика, Feb. 2016, No 1, C. 29-32.

29. Карнаух Богдан Петрович, Позовна давність у практиці європейського суду 3 прав людини, Проблеми законності, 2016, Вип. 134, С. 24-36. 
Buletsa, S., Zakrzewski, P., (2019)

Limitation of claims in Polish and Ukrainian Civil Code against the background of the principles of european contract law and the German Civil Code

30. Кодекс законів про працю від 10.12.1971 p. № 322-08. $\quad$ URL: http://zakon.rada.gov.ua/laws/show/322-08 (дата звернення: 14.07.2019).

31. Кодекс торговельного мореплавства від 23.05.1995 p. № 176/95-BP. URL: https://zakon.rada.gov.ua/laws/show/176/95-\%D0\%B2\%D1\%80 (дата звернення: 24.06.2019).

32. Онишко О. Б., Позовна давність в окремих країнах континентальної Європи та в Україні, Науковий вісник Львівського державного університету внутрішніх справ. Серія юридична, 2014, Вип. 2, С. 50-57.

33. Позовна давність: коментар судової практики / під ред. I. В. Спасибо-Фатєєвої. Цивілістична Платформа, Харків, 2016, С.50.

34. Постанова Верховного суду України від 22.03.2017 № 3-1486гс16, 5004/2115/11. URL: http://www.cct.com.ua/2017/22.03.2017_3-1486_16.htm (date of access: 2 April 2019).

35. Постанова Верховного Суду України від 27 квітня 2012 року у господарських справах.

URL:

http://www.scourt.gov.ua/clients/vsu/vsu.nsf/\%28documents\%29/33174C5514EC2572C22 57C92003A261E (date of access: 2 April 2019).

36. Про державний матеріальний резерв: Закон України від 01.08.2016. URL: https://zakon.rada.gov.ua/laws/show/51/97-\%D0\%B2\%D1\%80 (date of access: 2 April 2019).

37. Про деякі питання практики застосування позовної давності у вирішенні господарських спорів: Постанова Вищого господарського суду України від 29.05.2013 p. № 10. URL: http://zakon5.rada.gov.ua/laws/show/v0010600-13 (дата звернення: 19.08.2017).

38. Про захист прав споживачів: Закон України від 12.05.1991 р. № 1023-XII (в редакції від 01.12.2005 р. № 3161-IV). URL: http://zakon5.rada.gov.ua/laws/show/102312 (дата звернення: 24.06.2019).

39. Про практику розгляду судами трудових спорів: Постанова Верховного Суду від 06.11.1992 № 9. URL: http://zakon2.rada.gov.ua/laws/show/v0009700-92 (date of access: 2 April 2019).

40. Про страхування: Закон України від 07.03.1996 № 85/96-ВР Верховна Рада України. URL: http://zakon3.rada.gov.ua/laws/show/85/96-\%D0\%B2\%D1\%80 (date of access: 2 April 2019).

41. Ротань В.Г., Ярема А.Г., Кривенко В.В., Карабань В.Я., Сонін О.С. Науковопрактичний коментар до цивільного законодавства України . URL: http://uristinfo.net/2010-12-27-04-58-59/132-vgrotan-ta-in-komentar-do-tsku.html (date of access: 2 April 2019).

42. Романюк А. Б., Проблеми правового регулювання строків реалізації права на судовий захист, Прикарпатський юридичний вісник, 2016, Випуск 1 (10), С. 90-94.

43. Романюк В. А., До питання про визначення позовної давності як строку чи спливу строку, С. 22-24. URL: http://www.univer.km.ua/statti/romanyuk_v.a._do_pytannya_pro_vyznachennya_pozovnoy i_davnosti_yak_stroku_chy_splyvu_stroku_3.pdf (date of access: 2 April 2019).

88 sciendo Journal of Legal Studies Volume 24 Issue 38/2019 ISSN 2457-9017; Online ISSN 2392-7054.

Web: publicatii.uvvg.ro/index.php/jls. Pages $63-94$ 
Buletsa, S., Zakrzewski, P., (2019)

Limitation of claims in Polish and Ukrainian Civil Code against the background of the principles of european contract law and the German Civil Code

44. Сімейний кодекс України від 10.01.2002 p. № 2947-III. URL: http://zakon5.rada.gov.ua/laws/show/2947-14 (дата звернення: 14.07.2019).

45. Токар Н.В., Вимоги, на які позовна давність не поширюється. Право $і$ безпека, 2006, № 4, Т. 5, С. 131-134.

46. Шатковський Я.М., Проблемні питання щодо застосування позовної давності у вирішенні господарських спорів, Юридична наука, 2014, № 12, C. 14. URL: http://legal.nam.edu.ua/journal/n-12-2014.pdf (date of access: 2 April 2019).

\section{Notes}

[1] Bürgerliches Gesetzbuch, in der Fassung der Bekanntmachung vom 02.01.2002 (Bundesgesetzblatt, I S. 42, ber. Seite. 2909, 2003 Seite. 738) zuletzt geändert durch Gesetz vom 06.06.2017 (Bundesgesetzblatt, I S. 1495).

[2] Civil Code of Ukraine from 16.01.2003 № 435-IV. Reports of the Supreme Rada of Ukraine. 2003. № 40-44. ст.356

[3] See The Principles of European Contracts Law 2002 (Parts I, II, III). European Union. URL: http://www.jus.uio.no/lm//eu.contract.principles.parts.1.to.3.2002/sisu_manifest.html (date of access: 18 June 2018).

[4] Ustawa z dnia 23 kwietnia 1964 r. - Kodeks cywilny, tj. Dziennik Ustaw, 2017, pozycja 459.

[5] Sylwester Wójcik, Przedawnienie w prawie cywilnym po zmianie kodeksu cywilnego ustawą z 28 lipca 1990 r., Przegląd Sądowy, 1991, 1-2, p. 42.

[6] The Project of Civil Law Codification Commission http://www.projektkc.uj.edu.pl/index.php/projekty (date of access: 2 April 2019). The aim of Civil Law Codification Commission at Minister of Justice, working since 2006 was to prepare a project of a new civil code. The Commission of IVth term worked between 2011 and 2015 and it prepared the Project of the General Section of Civil Law. The Commission was dissolved in December 2015. In January 2016 heads of civil law departments from almost all law faculties in Poland decided to continue works on the project of a new civil code which was to be an academic project. This way the idea of Academic Project of Civil Law was born. URL: http://www.projektkc.uj.edu.pl/ (date of access: 2 April 2019). On 29th April 2016 general rules of working on the project were came through and the members of two committees were chosen: members of directive committee and editorial one.Next the members of problem teams were chosen. Within the framework of working on the project there are held recurrently organized scientific conferences dedicated legislative problems.

[7] Zob. Roman Trzaskowski, Roszczenia związane $\mathrm{z}$ prowadzeniem działalności gospodarczej w rozumieniu art. 118 k.c., Przegląd Sądowy, 2006, 2, pp. 3-15; Piotr Machnikowski, Przedawnienie roszczeń, in Edward Gniewek, Piotr Machnikowski (eds.). Kodeks cywilny. Komentarz, C. H. Beck, Warszawa, 2016, p. 282; wyrok SN z 8 kwietnia 2011 r., II CSK 434/10, LEX nr 1027169.

[8] Uchwała Sądu Najwyższego z 18 czerwca 2015 r., III CZP 31/15, (6, pozycja 67), Orzecznictwo Sądu Najwyższego Izba Cywilna”, (2016); Piotr Zakrzewski Komentarz do uchwały Sądu Najwyższego z 18 czerwca 2015 r., III CZP 31/15, Rocznik orzecznictwa $i$ 
Buletsa, S., Zakrzewski, P., (2019)

Limitation of claims in Polish and Ukrainian Civil Code against the background of the principles of european contract law and the German Civil Code

piśmiennictwa z zakresu prawa spółdzielczego, 2017, VII, p. 195; Piotr Zakrzewski, Przedawnienie roszczeń, in: Magdalena Habdas, Mariusz Fras (eds.), Kodeks cywilny. Komentarz, t. I. Część ogólna (art. 1-125), Wolters Kluwer, Warszawa, 2018, p. 966.

[9] Tekst jednolity Dz. U. z 2017 r. poz. 201, 648, 768.

[10] Zob. m.in. Piotr Zakrzewski, Przedawnienie w zasadach europejskiego prawa umów z perspektywy polskiej, Roczniki Nauk Prawnych, 2006, 16 (2), p. 78.

[11] Ibid., 79-80.

[12] Ibid., 80.

[13] Heinz-Peter Mansel, in R. Strüner (eds.) "Jauering Bürgerliches Gesetzbuch mit RomI, Rom-II, Rom-III-VO, EG-UntVO/HuntPrpt und EuErbVO. Komentar", (C.H.Beck, München, 2015), 161.

[14] $§ 2018$ of German civil code regulates actual heir 's claim versus legacy owner for legacy execution

[15] $§ 2130$ of German civil code regulates dummy heir's claim versus constituted heir for legacy execution

[16] $\S 2362$ of German civil code regulates a claim of an actual heir who is entitled to confirm an acquisition of the inheritance versus legacy owner who has got defective confirmation of acquisition of the inheritance for returning of this document to court

[17] German Civil Code https://www.gesetze-iminternet.de/englisch_bgb/englisch_bgb.html\#p0572 (date of access: 2 April 2019).

[18] Civil Code of Ukraine from 16.01.2003 № 435-IV. Records of the Supreme Council of Ukraine. 2003. № 40-44. p. 356

[19] Романюк В. А., До питання про визначення позовної давності як строку чи спливу строку, С. 22-24. URL: http://www.univer.km.ua/statti/romanyuk_v.a._do_pytannya_pro_vyznachennya_pozovnoy i_davnosti_yak_stroku_chy_splyvu_stroku_3.pdf (date of access: 2 April 2019).

[20] Онишко О. Б., Позовна давність в окремих країнах континентальної Свропи та в Україні, Науковий вісник Львівського державного університету внутрішніх справ. Серія юридична, 2014, Вип. 2, С. 50-57.

[21] Гуйван Петро, Теоретичні питання співвідношення присічних строків та строків позовної давності, Національний юридичний журнал: теорія і практика, Feb. 2016, No 1, C. 29-32.

[22] 1. On collection of a penalty; however, the penalty, the enforcement of which is envisaged in Part 2 of Article 785 of Ukrainian Civil Code is an independent property liability in the field of lease relations and is determined by the legislator as a double charge for the use of the thing during the delay, and therefore the application to it of a special limitation period provided for in paragraph 1, part 2 of Article 258 of Ukrainian Civil Code is incorrect.

2. On the refutation of inaccurate information placed in the media. In this case, the limitation period is calculated from the date of placing this information in the media or from the day that the person knew or could learn about this information;

90 sciendo Journal of Legal Studies Volume 24 Issue 38/2019 ISSN 2457-9017; Online ISSN 2392-7054.

Web: publicatii.uvvg.ro/index.php/jls. Pages $63-94$ 
Buletsa, S., Zakrzewski, P., (2019)

Limitation of claims in Polish and Ukrainian Civil Code against the background of the principles of european contract law and the German Civil Code

3. On the transfer to the co-owner of the rights and obligations of the buyer in case of violation of the preemptive right to purchase a share in the right of joint partial ownership (Article 362 of this Code);

4. Due to the shortcomings of the goods sold (Article 681 of this Code); Part 8 of Article 269 of the Commercial Code of Ukraine provides for a six-month period for filing claims arising from the supply of goods of inadequate quality. However, this is not one and the same term, but two different terms, since the first one of them (annual) applies to sales contracts (Article 655 of Ukrainian Civil Code ), and the second (six months) - supply contracts (Article 265 of the Commercial Code of Ukraine, Article 712 CC of Ukraine). The difference between them is that the law does not provide for the possibility of protecting the violated right in the event of a missed one, including for valid reasons, six months of filing a lawsuit. Consequently, in resolving the issue of the application of these terms to the Commercial court should carefully examine the legal nature of the contract concluded by the parties to the subject of its compliance with the signs of the contract of sale or supply.

5. About the termination of the gift contract (Article 728 of this Code);

6. In connection with the carriage of cargo, mail (Article 925 of this Code);

7. On appeal of actions of the executor of the will (article 1293 of this Code);

8. On the improper quality of work performed under a contract (Article 863 of this Code), however, it should be emphasized on buildings and structures used for 3 years.

9. The requirements relating to the contract of employment (Article 786 of Ukrainian Civil Code ). Claims for damages in connection with damage to a thing that was handed over to the employer, as well as claims for reimbursement of expenses for improvement of the thing, apply a limitation period of one year. The running of the limitation period in relation to the requirements of the employer begins with the moment of returning the thing by the employer, and, as far as the requirements of the tenant are concerned, from the moment the contract of employment is terminated. However, scientists believe that it would not be logical and contradict the essence of the institute of limitation, to extend the said provision to all requirements of the employer. on claims for compensation for losses incurred by the delayed transfer of property by the landlord, the requirements for the reimbursement of the cost of capital repairs performed by the lessee, if the landlord did not carry out major repairs that prevents its use in accordance with the purpose and conditions, and so on. Based on the nature of these violations, the tenant knows or should know that the relevant right has been violated since the moment of the violation, and therefore has the right to apply to the court with the relevant requirement, and therefore from that moment should begin the expiration of the limitation period rather than since the termination of the employment contract, which is fully in line with the essence of the institute of limitation and part 5 of Article 261 of Ukrainian Civil Code.

10. Consequences of non-payment of a check (Article 1106 of Ukrainian Civil Code ) - the requirements of the check holder for the payment of the check are subject to the limitation period of one year. In case of refusal of the payer to pay the check the check holder has the right to file a lawsuit. The holder of the security has the right to demand, in addition to 
Buletsa, S., Zakrzewski, P., (2019)

Limitation of claims in Polish and Ukrainian Civil Code against the background of the principles of european contract law and the German Civil Code

paying the check amount, the reimbursement of his expenses for payment, as well as interest.

[23] Позовна давність: коментар судової практики / під ред. І. В. Спасибо-Фатєєвої. Цивілістична Платформа, Харків, 2016, С.50.

[24] Про деякі питання практики застосування позовної давності у вирішенні господарських спорів: Постанова Вищого господарського суду України від 29.05.2013 p. № 10. URL: http://zakon5.rada.gov.ua/laws/show/v0010600-13 (дата звернення: 19.08.2017).

[25] Про захист прав споживачів: Закон України від 12.05 .1991 р. № 1023-XII (в редакції від 01.12.2005 р. № 3161-IV). URL: http://zakon5.rada.gov.ua/laws/show/102312 (дата звернення: 24.06.2019).

[26] Кодекс торговельного мореплавства від 23.05.1995 p. № 176/95-BP. URL: https://zakon.rada.gov.ua/laws/show/176/95-\%D0\%B2\%D1\%80 (дата звернення: 24.06.2019).

[27] Кодекс законів про працю від 10.12.1971 p. № 322-08. URL: http://zakon.rada.gov.ua/laws/show/322-08 (дата звернення: 14.07.2019).

[28] Сімейний кодекс України від 10.01.2002 p. № 2947-III. URL: http://zakon5.rada.gov.ua/laws/show/2947-14 (дата звернення: 14.07.2019).

[29] Господарський кодекс України від 16.01.2003 p. № 436-IV. URL: http://zakon0.rada.gov.ua/laws/show/436-15 (дата звернення: 14.07.2019).

[30] Карнаух Богдан Петрович, Позовна давність у практиці європейського суду 3 прав людини, Проблеми законності, 2016, Вип. 134, С. 24-36.

[31] Stubbings and Others v. The United Kingdom, no. 22083/93, § 51, ECHR, 1996-IV. HUDOC. URL: http://hudoc.echr.coe.int/eng?i=001-58079 (2 April 2019)

[32] Про державний матеріальний резерв: Закон України від 01.08.2016. URL: http://zakon5.rada.gov.ua/laws/show/51/97-\%D0\%B2\%D1\%80

http://zakon3.rada.gov.ua/laws/show/v0010600-13 (date of access: 2 April 2019).

[33] Токар Н.В., Вимоги, на які позовна давність не поширюється. Право $і$ безпека, 2006, № 4, T. 5, C. 131-134.

[34] See more: Jacek Zrałek, Przedawnienie w międzynarodowym obrocie handlowym, Zakamycze, Kraków, 2005, pp. 13-38, 56-68.

[35] Piotr Zakrzewski, op. cit., note 10, 81.

[36] An example of such a solution is shown in articles P442, 449/8 of Polish civil code.

[37] A good example to illustrate such a case is factual circumstances that became the basis for the judgment of the Supreme Court, referring to limitation of the claim for the realization of a bequest. The limitation period of that claim the Supreme Court made subject wanting to protect the entitled from the knowledge of the legatee, although legal rules give little base to such interpretation of article 970 and 981 of Polish civil code. The thesis of the judgment was as following: "The limitation period of a claim for the realization of a bequest begins on a day in which the legatee learnt about announcing the will. Verdict of the polish Supreme Court of February 15, 2001, II CZN 390/00, “Orzecznictwo Sądów Polskich”, (10) 2001, pozycja. 140, 477.

92 sciendo Journal of Legal Studies Volume 24 Issue 38/2019 ISSN 2457-9017; Online ISSN 2392-7054.

Web: publicatii.uvvg.ro/index.php/jls. Pages $63-94$ 
Buletsa, S., Zakrzewski, P., (2019)

Limitation of claims in Polish and Ukrainian Civil Code against the background of the principles of european contract law and the German Civil Code

[38] Reinhard Zimmermann, „... ut sit finis litum” Grundlinien eines modernen Verjährungsrechts auf rechtsvergleichender Grundlage", (18) Juristen Zeitung, (2000), 862; Piotr Zakrzewski, op. cit., note 10, 82-83.

[39] Reinhard Zimmermann, Detlef Leenen, H. P. Mansel, W. Ernst, "Finis Litum? Zum Verjährungsrechts nach dem Regirungsentwurf eines Schuldrechtsmodernisierungsgesetze", (13) Juristen Zeitung (2001), 687; Reinhard Zimmermann, op. cit., note 33, 862 .

[40] Jacek Zrałek, Przedawnienie roszczeń w polskim prawie cywilnym - szkic porównawczy, in Leszek Ogiegło, Wojciech Popiołek, Maciej Szpunar (eds), Rozprawy prawnicze. Księga pamiątkowa Profesora Maksymiliana Pazdana, Zakamycze, Poznań, 2005, p. 83.

[41] Господарський кодекс України від 16.01.2003 № 436-IV Верховна Рада України. URL: http://zakon3.rada.gov.ua/laws/show/436-15 (date of access: 2 April 2019).

[42] Постанова Верховного Суду України від 27 квітня 2012 року у господарських справах.

URL:

http://www.scourt.gov.ua/clients/vsu/vsu.nsf/\%28documents\%29/33174C5514EC2572C22 57C92003A261E (date of access: 2 April 2019).

[43] Resolution of the Supreme Court of Ukraine dated March 27, 2012, No. 3-20h12; Шатковський Я.М., Проблемні питання щодо застосування позовної давності у вирішенні господарських спорів, Юридична наука, 2014, № 12, С. 14. URL: http://legal.nam.edu.ua/journal/n-12-2014.pdf (date of access: 2 April 2019).

[44] Постанова Верховного суду України від 22.03.2017 № 3-1486гс16, 5004/2115/11. URL: http://www.cct.com.ua/2017/22.03.2017_3-1486_16.htm (date of access: 2 April 2019).

[45] Про деякі питання практики застосування позовної давності у вирішенні господарських спорів. Вищий господарський суд; Постанова від 29.05.2013 № 10. URL: http://zakon3.rada.gov.ua/laws/show/v0010600-13 (date of access: 2 April 2019).

[46] Про деякі питання практики застосування позовної давності у вирішенні господарських спорів. URL: Вищий господарський суд; Постанова від 29.05.2013 № 10. http://zakon3.rada.gov.ua/laws/show/v0010600-13 (date of access: 2 April 2019).

[47] Про практику розгляду судами трудових спорів: Постанова Верховного Суду від 06.11.1992 № 9. URL: http://zakon2.rada.gov.ua/laws/show/v0009700-92 (date of access: 2 April 2019).

[48] Кодекс законів про працю України_від 10.12.1971. Верховна Рада УРСР.. № 322VIII. URL: http://zakon2.rada.gov.ua/laws/show/322-08 (date of access: 2 April 2019).

[49] Романюк А. Б., Проблеми правового регулювання строків реалізації права на судовий захист, Прикарпатський юридичний вісник, 2016, Випуск 1 (10), С. 90-94.

[50] Did not not only «know» but also «could not know» is an obligatory condition for proceeding in the term of limitation of actions for satisfaction of solicitor of plaintiff. Верховний Суд України від 16 листопада 2016 р. у справі 6-2469-цс-16. URL: http://protokol.com.ua/ua/vsu_ne_tilki_ne_znav_a_i_ne_mig_dovidatis_obov_yazkova_um ova_dlya_ponovlennya_stroku_pozovnoi_davnosti/ (date of access: 2 April 2019). 
Buletsa, S., Zakrzewski, P., (2019)

Limitation of claims in Polish and Ukrainian Civil Code against the background of the principles of european contract law and the German Civil Code

[51] Аналіз судової практики внаслідок застосування судами роз'яснень, викладених у Постанові Пленуму ВСУ «Про судову практику розгляду цивільних справ про визнання правочинів недійсними». URL:

http://protokol.com.ua/ru/vssu_analiz_sudovoi_praktiki_pri_zastosuvanni_sudami_roz_yas nen_vikladenih_u_post_plenumu_vsu/ (date of access: 2 April 2019).

[52] The running of the limitation period on the claims of the creditor, which arises from violation of the debtor terms of the contract on repayment of debt parts begins with each separate part. Suprem Court of Ukraine. 05.04.2017. № 6-522-цс-17) URL: http://protokol.com.ua/ua/vsu_perebig_pozovnoi_davnosti_za_vimogami_kreditora_yaki_v iplivayut_z_porushennya_borgnikom_umov_dogovoru_pro_pogashennya_borgu_chastina mipochinaetsya_stosovno_kognoi_okremoi_chastini_(vsu_vid_05_04_2017_6_522tss17)/ (date of access: 2 April 2019).

[53] Про страхування: Закон України від 07.03.1996 № 85/96-ВР Верховна Рада України. URL: http://zakon3.rada.gov.ua/laws/show/85/96-\%D0\%B2\%D1\%80 (date of access: 2 April 2019).

[54] Ротань В.Г., Ярема А.Г., Кривенко В.В., Карабань В.Я., Сонін О.С. Науковопрактичний коментар до цивільного законодавства України . URL: http://uristinfo.net/2010-12-27-04-58-59/132-vgrotan-ta-in-komentar-do-tsku.html (date of access: 2 April 2019).

[55] Piotr Zakrzewski, op. cit., note 10, 84.

[56] Resolution of the 7 Supreme Court Judges of January 26, 2005, III CZP, 42/04, Orzecznictwo Sądów Polskich, 2006, z. 3, s. 3.

[57] Jürgen Ellenberger, in "Palandt. Bürgerliches Gesetzbuch“, C. H. Beck, München, 2010, pp. 219-220. 